QUADERNS DE FILOSOFIA VOL. VIII NÚM. I (202 I): 37-59

eISSN: 234 I-3042 DOI: I 0.7203/QFIA. 8.I.2032I

Bosco Corrales Trillo

Universidad Católica de Valencia "San Vicente Mártir"

\title{
(Not) Hosting Refugees in the EU: Philosophical Perspectives on the 2015-2016 Crisis
}

La (no) acogida de personas refugiadas en la UE: perspectivas filosóficas sobre la crisis de 2015-2016

Recibido: 3/2/2021. Aceptado: 13/5/2021

\begin{abstract}
Were the EU's actions in terms of refugee hosting during the 2015-2016 crisis morally acceptable? This paper describes those actions and evaluates them from the points of view of philosophers who specialize in the field of asylum ethics, such as Joseph Carens, Matthew Gibney, or David Miller, among others. First, I clarify who, according to such literature, would be entitled to refugee or refugee-like protection. Secondly, I indicate to what those persons would be entitled. Thirdly, I explain why the EU fell short of its moral obligations towards those people, and finally, I advance a few suggestions for improvement.
\end{abstract}

Resumen: ¿Fue moralmente aceptable la actuación de la UE en cuanto a la acogida de personas refugiadas durante la crisis de 2015-2016? Este artículo describe dichas acciones y las evalúa desde el punto de vista de autores como Joseph Carens, Matthew Gibney o David Miller, entre otros. En primer lugar, aclaro qué personas tendrían derecho a protección internacional según los mencionados autores. En segundo lugar, indico a qué tendrían derecho aquellas personas. En tercer lugar, explico por qué la UE no estuvo a la altura de sus obligaciones morales hacia ellas y, por último, apunto algunas sugerencias de mejora.

Keywords: ethics, refugees, international protection, European Union, ideal and non-ideal theory.

Palabras clave: ética, personas refugiadas, protección internacional, Unión Europea, teoría ideal y no ideal. 


\section{INTRODUCTION}

Tn June 2015, Nils Muiznieks, the Council of Europe's Commissioner for Human Rights, wrote a very critical op-ed article in The New York Times with the title "You are better than this, Europe" (Muiznieks 2015). He considered that the response of most European countries to the refugee crisis had been shameful. Immigration management is certainly a complex and difficult issue, but we "must not use this difficulty as an excuse to trample on our obligations to protect those who flee wars and persecution", he said. During the following year, he repeatedly denounced what he considered to be outrageously immoral actions by the EU and its Member States (MuiznieKs 20 I 6A; 20 I6B; 20 I6C).

I believe that Europe — as Mr. Muiznieks put it - trampled on its moral obligations towards refugees. However, as I try to make the case in the form of a philosophical research paper, the issue is so complex, the items to assess are so varied, and the opinions and arguments by the different authors so numerous and divergent, that the attempt at a rigorous and systematic ethical assessment of the EU's performance in the refugee crisis of 2015-2016 presents itself as an overwhelming task. This paper is just a first and modest — but thorough - approach to the issue, based on the theoretical proposals of some well-established philosophers, who specialize in the field of asylum ethics.

First, I shall offer some highlights of the EU's and its Member States' hosting actions during the crisis (section 1), in order to, then, explore to what extent they fulfilled their moral obligations, according to some accounts of moral responsibility to refugees in the recent, specialized philosophical literature. This I do in three steps: I shall first define who is entitled to international protection (section 2), secondly, I shall indicate to what they are entitled (section 3), and thirdly, I shall explain why, according to surveyed philosophical literature, EU States failed to fulfill their moral obligations to refugees in terms of hosting (section 4). Finally, I shall offer a brief conclusion (section 5) and advance a few suggestions on how EU States could or should have acted, based on the accounts of moral responsibility previously outlined; these suggestions are also meant as modest proposals to improve current refugee policies (section 6).

I. How did the EU ANd Its Member States Respond to the REFUGEe CRISIS OF 2OI 5-2OI6?

In this section, I shall indicate some of the most relevant actions of the EU and its Member States in terms of hosting refugees and contributing to fund protection elsewhere. 
With regard to hosting refugees, EU institutions were not able to accomplish much, due to the very different stances of the Member States concerning asylum. After much protracted debate, the European Council managed to introduce relocation quotas to alleviate pressure on the EU Member States that served as entry points - mainly Greece and Italy-. First, the Council agreed on the relocation of 40,000 persons in need of international protection, from Italy and Greece to other EU Member States (Council OF THE EU 20I 5B). A few months later, due to the rise in arrivals of asylum seekers, a resolution was adopted to relocate additional 120,000 people (Council of THE EU 20I5C). Previously, the Council had agreed on resettling 22,504 persons in need of international protection from outside the EU (CounCIL Of THE EU 20I5A). However, most of those people ended up not being relocated, as we will see next.

EU Member States acted in very different ways, with regard to admitting asylum seekers and granting them international protection. In total, the whole of the EU countries granted asylum or other forms of international protection to over 900,000 people during 2015 and 2016 (European Parliament 20 I7). However, most of the effort was done by five or six countries, while many of the others dragged and lagged. Germany granted protection to approximately half of those $900,000^{1}$ refugees in that two-year period; in addition, by the end of 2016, it had admitted a total of 587,346 asylum seekers with pending cases in its territory, thus becoming the champion of asylum during the crisis. The next top host countries in the EU during the 2015-2016 period were: Sweden, which granted protection to nearly 90,000 new refugees; France and Italy, each of them granting official protection approximately to 50,000 people; then, Greece, with roughly 40,000; Austria, over 30,000; the Netherlands, around 20,000; Denmark, 15,000; and Belgium, 12,000. Conversely, the main trend in most EU countries was very different. Some countries only granted asylum to a few hundred and some, to none. For instance, Ireland, Poland, and Croatia did not grant asylum to any new applicant. Latvia granted asylum to 149 people; Slovenia, to 162; Slovakia, to 190; Estonia, to 222; Lithuania, to 288; Portugal, to 494; and Czech Republic, to 644. The other EU States granted asylum to 1,000-7,000 applicants, but many of them were already there before the refugee crisis broke loose in 2015. Spain, for example, granted asylum to over 6,000 people, but most of them were already there before 2015. In fact, within the frame of the 2015 relocation quotas, Spain had committed to grant asylum to 17,337 refugees before September 2017, but it only granted it to 1,980. Similarly, many EU States did not meet their quotas and the EU relocation plan was a complete failure: out of the 160,000 refugees that EU Mem-

${ }^{1}$ The figures in this paragraph have been calculated comparing the UNHCR data from 2016
and 2014. See UNHCR (2017C, 6-9, Table I) and UNHCR (2015, 80-3, Table I). 
ber States had agreed to relocate before September 2017, they only relocated 31,503 (European Commission 20 i7b).

Concerning refugee protection elsewhere, the $\mathrm{EU}$ is the third top donor to the UNHCR worldwide, with donations made in the amount of 436 million USD in 2017, the first donor being the USA (with over 1.45 billion) and the second, Germany (with over 576 million) (Donors n.d.).

Besides donating to the UNHCR, the EU humanitarian funding was remarkable. For instance, in 2016 alone, EU Civil Protection and Humanitarian Aid gave almost 2 billion for the support of forcibly displaced people and their host communities in 56 countries (Turkey, Greece, Syria, Iraq and South Sudan being the top five) (European Commission n.d.). During 2016 and 2017, 1.4 billion euros were provided by the EU to fund humanitarian aid under the Facility for Refugees in Turkey (TuRKEY n.d.). Since the beginning of the Syrian war and until 2017, 340 million euros had been given for the protection of refugees in Jordan (JoRDAN n.d.) and 519 million for Lebanon (LeBANON n.d.). For the period 2015-2017, the EU humanitarian funding for both displaced Iraqis and Syrian refugees inside Iraq, totaled 349 million euros (IraQ n.d.). From 2009 to 2017, 554.4 million euros had been dedicated to provide humanitarian aid in Pakistan for Afghan refugees, as well as for Pakistani people affected by the conflict in the northwest and by food insecurity (PAKistan n.d.). In 2017, the EU allocated 85 million euros to provide help for the more than one million South Sudanese refugees in Uganda, as well as Congolese, Burundian, and other refugees in that country (UGANDA n.d.). These are only some of the most significant EU actions in relation to protecting refugees elsewhere. We can safely affirm that the $\mathrm{EU}$ is very much committed to this line of protection.

In conclusion, we can say that the EU and some Member States contributed greatly to the protection of refugees. However, depending on how we define the EU's and its Member States' moral obligations toward refugees, we may conclude that most States — and even the EU in some aspects - failed to fulfil those obligations.

I shall next define who was entitled to protection by EU States and to what they were entitled, and then, assess whether those States lived up to their responsibilities toward them.

\section{WHO WAS ENTITLED TO INTERNATIONAL PROTECTION IN THE EU?}

The Universal Declaration of Human Rights states that "everyone has the right to seek and to enjoy in other countries asylum from persecution" (Art. 14, 1). It is true that, according to the Geneva Convention, a "refugee" is a forcibly 
displaced person who is being persecuted for reasons of race, religion, nationality, membership of a particular social group, or political opinion. ${ }^{2}$ In this sense, only a small number of forcibly displaced persons (FDPs) are refugees, strictly speaking, and have therefore a right to seek and enjoy asylum. However, there are other legal concepts that express the States' duty to host FDPs seeking protection.

In EU Member States, "when examining applications for international protection, the determining authority shall first determine whether the applicants qualify as refugees and, if not, determine whether the applicants are eligible for subsidiary protection" (Directive 2013/32/ EU). Any FDPs who, if returned to their countries, would face real risk of serious harm, are eligible for subsidiary protection (Directive 20I I/95/ EU, art. 2, e). ${ }^{3}$ Serious harm includes, among other instances, "serious and individual threat to a civilian's life or person by reason of indiscriminate violence in situations of international or internal armed conflict" (Directive 20 i I/95/EU, art. 15, c).

This status would apply to most of the, approximately, 6 million Syrian nationals forcibly displaced outside of Syria at the end of 2016, or to most of the millions of Afghan, Iraqi, South Sudanese citizens and a sadly very long list of other nationals forced to leave their countries due to violence and war. As a matter of fact, 50-61\% of the more than 2.5 million asylum seekers that filed applications in EU countries during 2015-2016 were found eligible for international protection (European Parliament 20I7). Several other millions were not allowed to arrive; had they reached an EU border, States would have had to process their cases and, given the situation in their countries of origin, it can be easily assumed that a similar percentage would have qualified for subsidiary protection (a status similar to asylum).

It is clear, from this legislation, that the EU and its Member States have very specific legal duties in terms of hosting and assisting refugees, as well as other kinds of FDPs. Consequently, even if one were to argue that article 14, 1 of the Universal Declaration of Human Rights does not necessarily imply for every country a duty to host, and even if most so called "refugees" would not qualify as such under the Geneva Convention, the EU has made surely ex-

${ }^{2} 1951$ UN Convention Relating to the Status of Refugees, article 1 A(2): "Any person who: owing to a well-founded fear of being persecuted for reasons of race, religion, nationality, membership of a particular social group, or political opinion, is outside the country of his nationality, and is unable to or, owing to such fear, is unwilling to avail himself of the protection of that country."

${ }^{3}$ Directive 2011/95/EU: "A 'person eligible for subsidiary protection' means a third country national or a stateless person who does not qualify as a refugee but in respect of whom substantial grounds have been shown for believing that the person concerned, if returned to his or her country of origin, or in the case of a stateless person, to his or her country of former habitual residence, would face a real risk of suffering serious harm." This definition has been in force since 2004 (See Council Directive 2004/83/EC). 
plicit that its Member States do have the duty to host and protect sensu stricto refugees and many other people needing international protection of different kinds, when they apply for it.

There are other bodies of international law that either oblige or urge the $\mathrm{EU}$ to protect refugees and FDPs to different degrees, ${ }^{4}$ but the most recent, as well as the most comprehensive and demanding document with regard to refugee protection up to 2016 was the New York Declaration for Refugees and Migrants adopted by the UN General Assembly on September 19, 2016 (United Nations 20i6). 5 Among the bold commitments contained in the document, I consider the pledge to "find new homes for all refugees identified by UNHCR as needing resettlement" (New York Declaration n.d.), to be the one that best exemplifies the moral obligation to render aid to refugees.

Not just convention refugees, but refugees in the broad sense of the term. The New York Declaration uses the term "refugee" in that sense, following the UNHCR definition of "refugee". The UNHCR has enlarged the Geneva Convention definition of a "refugee", to include what the EU legislation considers "persons eligible for subsidiary protection" (GLOSSARY n.d.). ${ }^{6}$

${ }^{4}$ The European Convention on Human Rights prohibits the collective expulsion of aliens and prescribes certain procedural safeguards relating to the expulsion of individual aliens (European Convention on Human Rights, Protocol 4, art. 4 and Protocol 7, art. 1). This Convention is an international Treaty legally binding for all the members of the Council of Europe, which includes all EU countries. The EU itself is in the process of becoming a member too.

The Charter of Fundamental Rights of the European Union states that "the right to asylum shall be guaranteed with due respect for the rules of the Geneva Convention of 28 July 1951 and the Protocol of 31 January 1967 relating to the status of refugees and in accordance with the Treaty on European Union and the Treaty on the Functioning of the European Union" (art. 18). It adds that "collective expulsions are prohibited" (art. 19,1) and that "no one may be removed, expelled or extradited to a State where there is a serious risk that he or she would be subjected to the death penalty, torture or other inhuman or degrading treatment or punishment" (art. 19,2).

The Treaty on the Functioning of the European Union declares: "The Union shall develop a common policy on asylum, subsidiary protection and temporary protection with a view to offering appropriate status to any third-country national requiring international protection and ensuring compliance with the principle of non-refoulement" (art. 78, 1).

The UN General Assembly Resolution 69/167 of December 2014, stresses "the obligation of States to protect the human rights of migrants regardless of their migration status" and calls upon them to promote and effectively protect their rights and fundamental freedoms ("Resolution 69/167. Protection of Migrants," UN General Assembly, December 18, 2014).

${ }^{5}$ In December 2018 the UN agreed on a new deal known as "the global compact on refugees" (https://www.unhcr.org/a-new-deal-for-refugees.html), but it is beyond the scope of this paper, since we are trying to assess the EU's response to the 2015-2016 refugee crisis.

${ }^{6}$ The UNHCR has added the following to the Geneva definition: “(...) or [a person] who is outside his/her country of origin or habitual residence and is unable to return there because of serious and indiscriminate threats to life, physical integrity or freedom resulting from generalized violence or events seriously disturbing public order (OAU Convention and Cartagena Declaration)" (GLOSSARY n. d.). 
This definition practically includes any person who, being forcibly displaced because of generalized violence, has crossed an international border. It virtually coincides with the definition of a "refugee" that authors like Matthew Gibney (2004 and 2018) or Joseph Carens (2013) use in their argumentations.

There is an ongoing academic discussion on whether the definition of "refugee" should be expanded or not. ${ }^{7}$ In a recent paper, Max Cherem argued that the refugee definition should not be expanded, because it would hurt the special case of refugees in the strict sense of the word and it would not necessarily benefit other kinds of forcibly displaced persons (CHEREM 20I6, 18796). He and others defending the same position - like M. Price, M. Lister, etc. - might perhaps be right in their contention against expanding the definition, but the fact is that the UNHCR has already expanded it and the UN Resolution 71/1 — signed by all EU States - is assuming such expansion. In any case, even if one were to argue that people fleeing generalized violence are not refugees, EU Member States would still have to act in compliance with the Council and Parliament Directives and apply the subsidiary protection status, which offers most of the benefits of refugee protection. Therefore, although the academic discussion is still open, I shall use the term refugee following the definitions of Gibney (2004 and 2018) or Carens (2013), because it essentially coincides with the UNHCR notion and with the EU definition of persons entitled to international protection in its Member States (going forward I shall use the term "refugee" in this extended sense, unless otherwise indicated).

\section{TO WHAT ARE REFUgeES ENTITLED?}

Some theorists, like Christopher H. Wellman, have argued that refugees only have a right to protection from their persecutors (Wellman and Cole 20II). This would only entail a safe haven where their life and physical integrity were not at risk. However, this contention is linked to both a narrow definition of refugees - exclusively as those fleeing persecution - and a rather partialist or nationalist understanding of States' duties.

Conversely, most ethicists believe that refugees are entitled to the full range of human rights. At first, bare physical safety, food, and shelter can do in the short term, as immediate relieve. Then, however, civil and political as well as socio-economic rights must be progressively secured. This is the view not only of liberal cosmopolitans like Carens (2013) and others, but also of moder-

${ }^{7}$ For a most recent and thorough discussion on the topic, see Cherem (2016) or Miller (2016, chapter 5). See also Gibney (2004 and 2018), Carens (2013), or Betts (2015), especially the text pertaining to notes 15-18 and the several studies referenced in those notes. 
ate humanitarians like Gibney (2004), and even rather conservative communitarians like David Miller (2016). Also Martha Nussbaum, even considering cosmopolitanism to be a flawed theory, has recently insisted - quoting Grotius - that, "in a time of emergency our common claim, as human beings, to the wherewithal of life should dictate a liberal asylum policy" (Nussbaum 2019, 223). Furthermore, she considers that it is wrong to separate first and second-generation human rights, because without economic security, education, or health, it is not possible to exercise our civil and political liberties adequately.

Moreover, that refugees should be granted the full range of human rights is not only the conviction of philosophers, but it is contemplated in the law of any democratic State and very explicitly and particularly in the EU laws of international protection. According to Directive 2011/95/EU, arts. 20-35, both convention refugees and people eligible for subsidiary protection have a right to protection from refoulement, to receiving information, maintaining family unity, residence permits, travel documents, access to employment, access to education, social welfare, health care, and access to accommodation.

In addition, in many EU States, there is a third protection device called "authorization to stay for humanitarian reasons", which entails full human rights protection. In other democratic countries, there are other forms of international protection, such as "temporary protected status" in the USA, or "persons in need of protection" in Canada, and so on. While not all these statuses include citizenship or permanent integration in the host society, they all guarantee civil liberties and socio-economic rights for the duration of the hosting time.

May these brief insights from different philosophical approaches and from democratic States' legislation suffice to make clear that refugees are entitled to full human rights protection. However, this does not necessarily mean that such protection must be provided through asylum in rich countries. Funding and securing refugee protection in third countries can be an acceptable alternative, as we shall see.

\section{Did EU States FUlfil their Moral obligations toward REFUgeES?}

The implication of the two previous sections is that, in 2015, EU countries were looking at several million people potentially arriving at its borders in just a few months and being entitled to enjoy protection in the EU if they applied for it. What should EU countries have done? Were they supposed to let them all come and apply for it? Where they morally obliged to take them 
all in? Could they justifiably refuse to admit them? Under what criteria? Was externalizing borders and funding protection elsewhere a morally justifiable substitute for admitting refugees into the EU? I shall address these questions in the remainder of this paper.

Practically all theorists agree that States have some moral obligations to refugees (MiLler 2019). Most authors agree that refugee protection should be distributed equitably amongst States, so that each State is responsible for its fair share of refugee protection (Gibney 2004; Carens 20I3; Miller 2019; and others). Some believe that developed countries should provide such protection mainly by hosting refugees (CARENS 20I3; OWEN 20I6A and 20I6B; Cortina 2017). Others consider protection elsewhere (securing refugee protection in a third country) to be an ethically acceptable substitute for hosting and integrating (Betts and Collier 2017; Gibney 2004; Miller 2016 and 2019; Wellman 2016). Michelle Foster, for instance, presents several acceptable protection elsewhere schemes (FOSTER 2007).

Did EU countries admit a fair amount of refugees during the 2015-2016 crisis? If not, did they fulfil their responsibilities to refugees by securing their human rights in third countries? I shall first discuss the hosting numbers and then turn to examine the protection elsewhere option.

It is not easy to ascertain any given country's fair share of refugee protection. GDP, total number of refugees in the world, and the host country population size, are commonly used as standards to measure a State's fair share of refugee resettlement (Gibney 201 5, 9f.). GDP per capita measured in Purchase Power Parity would also be a very relevant item (OWEN 2016B), as well as causal responsibility (MiLleR 2007, 86f.) among several other complex factors. In addition, if we want to measure not only the fair share of refugee protection by hosting, but also by outsourcing protection to third countries, the equation becomes even more complicated. The issue is intricate. However, for the sake of thinking the issue philosophically, without needing to be an expert in refugee demographics, perhaps I could try to indicate a very gross estimate of a plainly arithmetic distribution, to give ourselves a number from which we could start debating.

At the end of 2016, there were 17.2 million refugees under UNHCR mandate worldwide (UNHCR 20 I7B). If there are 194 countries in the world, each country should be responsible for the adequate protection of 88,659 refugees. By "adequate", I mean granting asylum or other forms of international protection in their own territory, or securing their protection in a third country that guarantees full human rights protection. This is a simple division and it is not indicative of how many refugees should a given country be really responsible for, but it seems to be a safe demand for rich democratic coun- 
tries. If anything, the fair share figure should be higher for rich democratic countries and lower for poorer countries and for failed, refugee-producing, or crisis-ridden States. Yet, by the end of 2016, only eight EU States were hosting 88,000 refugees or more (UNHCR 2017B, 61-64, Annex Table I). Consequently, unless they were securing adequate protection elsewhere, the other EU countries' level of fulfilment of their moral obligations to refugees would have been questionable.

Admittedly, some authors and many governments will consider that securing adequate protection for 88,000 refugees is an excessive burden even for some EU States, depending on their economic growth, their public spending, public debt, unemployment rates, etc. For the sake of making prescriptions that could be acceptable for those governments, let's be extremely conservative and divide our simple arithmetic distribution by ten: 8,800. Again, according to the numbers provided by the UNHCR (2017B), only fourteen EU countries were hosting 8,800 refugees or more. I believe that, even being conservative, if they were not hosting a tenth of the arithmetic distribution and unless they were providing adequate protection elsewhere, it is safe to argue that most EU countries were probably not doing their fair share.

Before the European refugee crisis, I would have agreed with Carens, who did not see "how any democratic state in Europe or North America today could make the case that it has taken in so many refugees that it is now morally entitled to turn real refugees away" (CARENS 2013, 220). At the height of 2016, his statement needed further qualification. Germany -with 669,482 refugees and 587,346 pending asylum cases - had possibly reached and surpassed its fair share. France (approx. 370,000) or Sweden $(313,000)$ could also make that case. Perhaps Italy, Austria, Greece, the Netherlands, and the UK could argue that they were doing their part too. However, Carens' evaluation would still apply to, at least, fourteen EU States, unless - again - they were effectively and adequately providing human rights protection in a third country. I shall discuss that possibility below, but first, we shall take a brief look at the world's refugee population.

If we look at the global picture, the unfair distribution of refugees looks much starker. At the end of 2016, after the greatest rise in asylum seekers worldwide, $84 \%$ of the refugees were being hosted by developing and least developed countries, while developed and rich countries were refusing to take in any more refugees. For instance, the EU, with approximately 10 times the GDP of Turkey, was hosting roughly the same number of people; with 20 times the GDP of Pakistan, the EU was hosting only twice as many people; with 12.5 times the GDP of Iran, it was hosting only three times as many peo- 
ple; and with 335 times the GDP of Lebanon, it was hosting only three times as many people. ${ }^{8}$ The meager asylum figures in most European countries did not seem to justify a moral entitlement to turn refugees away.

Were EU States delivering their fair share of responsibilities by providing protection elsewhere? There is a number of reasons suggesting that protection in third countries could be a morally acceptable or even recommendable option. Some EU countries could lack absorptive capacity due to population density, inability to create enough jobs, economic crisis, potential political backlash, or public hostility. Another reason is that the cost of determining who is entitled to protection and providing such protection in rich countries is much higher than doing so in poor ones. Consequently, rich countries could afford providing protection for many more refugees if they outsourced their determination and protection mechanisms to developing ones. There are several other reasons in favor and against the moral rightness of providing refugee protection in third countries. In fact, there is an extensive debate on the matter (BetTs and Collier 20 I7; GibNey 2004, 215-20; Carens 20i3 3, 214-5; Miller 20i6, 85-93; Owen 20i6a; WellMAN 2OI6).

Although the debate is completely open, I shall here assume - for the sake of the argument and for the sake of making prescriptions that real EU governments would feel compelled to follow- that there is nothing wrong per se with liberal democracies outsourcing (at least part of) their fair share of refugee protection. Even in that case, however, we would still have to introduce at least two provisions to make protection elsewhere schemes morally sound. First, they should be based on bilateral or multilateral agreements (Cherem 20i 6; SANDELIND 20 I7); it would not be fair to just assume that any of the current host countries in the developing world must keep the refugees without its deliberate and explicit consent. Second, those schemes should guarantee full integration opportunities for refugees in the host society (SANDELIND 2017). Refugees are not only entitled to basic rights protection, like safety, food, or shelter. This may be enough in the short term, but in the long run, they are entitled to the full range of human rights, just

\footnotetext{
${ }^{8}$ On the one hand, Turkey, with a GDP of 2 trillion international \$, was hosting 2.9 million refugees. Pakistan, with a GDP of 1 trillion, was hosting 1.4 million refugees. Lebanon, with 85.9 billion, was hosting 1 million. Iran, with 1.6 trillion, was hosting 979,400. On the other hand, the EU Member States, with 20.3 trillion, were hosting less than 1.9 million refugees and 1.1 million asylum seekers with pending cases. The GDP figures are presented in PPP (purchasing power parity) to compensate for the dissimilar cost of living in the different countries. See "GDP, PPP (current international \$)," World Bank, accessed June 4, 2018, https://data. worldbank.org/indicator/NY.GDP.MKTP.PP.CD?year_high_desc=true. The number of refugees hosted in each country are taken from UNHCR (2017C, 6-9, Table I)
} 
like any other member of the society they are living in, which would ideally - but not necessarily - include permanent residency or even citizenship (Carens 2013; Gibney 2004; OWen 20i6a and 2019). Therefore, without guaranteeing full integration opportunities —education, jobs, career, political participation, some kind of long-term residency, etc.-, the funding State would still be failing to fulfil its moral obligations towards refugees.

Betts and Collier (2017) consider that the existing refugee protection models in developing countries are dysfunctional and undermine the autonomy and dignity of refugees. Sandelind $(2017,19)$ has argued that virtually none of the protection elsewhere schemes of the EU and its Member States qualify as acceptable under these two provisions. Either they are not based on bilateral agreements or they do not guarantee integration (often, they do not even guarantee basic rights). Donating to the UNHCR does not guarantee refugee integration or fundamental rights protection. In fact, most of the time, such integration never happens, but refugees end up living in protracted situations of encampment without barely any prospects of being able to lead a dignified life. Funding refugee protection in third countries through humanitarian aid does not guarantee integration either and most of the time, is not based on bilateral agreements, but on the de facto assumption that refugees are staying in Lebanon or Jordan, for instance. The deal with Turkey would be an exception, since it was based on a bilateral agreement, but the scheme did not guarantee full protection of human rights and integration.

In fact, the 2016 EU-Turkey agreement has been considered by many as "shameful" (Bulley 2017; Gogou 2017). Strategically, it was successful: it reduced drastically the arrivals of migrants from Turkey to Europe and it can be said to be one of the most effective responses to the high rise in refugee flow. Ethically, however, it could be considered a low point in EU history of refugee protection and even a shame.

It was not shameful to ask Turkey to prevent departures from their coast by fighting the abominable human-smuggling mafias. Fighting crime was Turkey's duty all along, which begs the question of why the need for an agreement with the EU, why Turkey was not fulfilling its duty, and whether it was neglecting it purposely. Not that Turkey had the duty to stop people from leaving the country, but most of those leaving by sea, were doing so with the help of unscrupulous mafias, which exploited their weakness, obtained huge illegal gains by extorting their money out of them, and finally let them on their own to a likely death by drowning in the sea. Again, the shameful part was not, as I said, asking Turkey to fulfil its duty and stop the criminal smuggling business. What was shameful was the fact that a union of 28 countries, with circa 500 million inhabitants, a GDP of 20 trillion, 
and a GDP per capita of almost 40,000, ${ }^{9}$ refused to host more than 3 million refugees, while it asked Turkey to take care of the same amount of people: a country with 80 million inhabitants, a GDP of 2 trillion, a GDP per capita of 25,000, and an infant mortality rate of 11 (as opposed to the EU's $3),{ }^{10}$ in addition to many other problematic issues.

It was not shameful to try and effectively reduce the migrants flow by sea, consequently preventing thousands of deaths. What was shameful was that the EU did not give the refugees any alternative option to apply for asylum, but it closed the door to hundreds of thousands of people in clear need of international protection, declaring that they would be returned if caught, which made the deal with Turkey not only ethically reprehensible, but also legally dubious. For these and other reasons, the EU-Turkey agreement continued to be strongly criticized by NGOs and migration policy experts, "who rightly questioned Turkey's status as a safe country of return, as well as a number of other issues of legality" (Ardittis 20i6). Also the Human Rights Commissioner of the Council of Europe repeatedly criticized a deal that he considered to elicit serious concerns from a human rights perspective and to be both morally and legally highly questionable (MuiznieKs 2016A; 2016B; 2016C).

It would have been ethically correct, if the deal had guaranteed human rights protection and provided long-term integration policies, but it only provided 6 billion euros for refugee protection, which, given the amount of refugees it required Turkey to take in, equaled to less than 2,000 euros per refugee. Such funding could barely cover the cost of short-term basic rights protection, let alone long-term full human rights protection.

For all these reasons, I am much inclined to concur with Cortina's assessment that the EU deal with Turkey was the result of "political panicking", rather than of well-pondered democratic debate (Cortina and TorreblanCa 20I6).

In addition to asking Turkey to stem the flow of asylum seekers, other policies and measures were put in place to prevent refugees from reaching EU borders, without providing acceptable protection elsewhere as a remedial device. EU Member States implemented systematic, coercive, and prolonged detention of migrants and asylum seekers in contrast with international human rights law (MajCher 2017). The EU arranged a militarized naval blockade coordinated by its border agency Frontex, carried out operations to destroy smugglers' boats and return migrants to points of origin, and exercised pressure on North African

\footnotetext{
${ }^{9}$ The figures are presented in PPP and measured in international \$. See "GDP per capita, PPP (current international \$)," World Bank, accessed June 4, 2018, https://data.worldbank.org/ indicator/NY.GDP.PCAP.PP.CD.

10 "Mortality rate, infant (per 1,000 live births)," World Bank, accessed June 5, 2018, https:// data.worldbank.org/indicator/SP.DYN.IMRT.IN.
} 
governments to create holding camps along the southern Mediterranean coast (Hsu 2017, 8-9 and footnotes 16-19), without ensuring human rights protection for refugees in an adequate manner.

A Migration Partnership Framework was set up in June 2016 to support African countries of origin and transit with substantial funding and technical assistance, in order to help them stop irregular migration directed to the EU (European Commission 20i6). It was presented as a "new approach to better manage migration" with the objective "of saving lives" and yet, it was strongly condemned in a joint statement of $131 \mathrm{NGOs}$ as being chiefly an attempt to stop migration from reaching the EU (Joint NGO statement). Although the EU communiqué explicitly declares to aim at "stemming the irregular flows while offering legal migration channels, including increased resettlement efforts", such channels and efforts have been rather small. Even after having committed to finding "new homes for all refugees identified by UNHCR as needing resettlement" (New York Declaration n.d.) (United Nations 2016, \$78), out of the 1.2 million identified by UNHCR for 2018 (UNHCR $2017 \mathrm{~A})$, the European Commission recommended the resettlement of 50.000 until October 2019 (European Commission 20I7A). It is certainly an "increased" effort if compared with the less than symbolic 22,504 refugees the EU Member States agreed on resettling in 2015 (CouncIL OF THE EU 20 I 5A), but it is very far from enough, considering the real needs, the EU countries' ability to host and their commitment to the New York Declaration.

These are some of the instances that show very clearly that the EU and most Member States were mainly working on strengthening the walls of a "Fortress-Europe" and externalizing borders in order to keep migrants and refugees out of the Schengen area, without ensuring ethically acceptable refugee protection elsewhere. The case for the EU and many of its Member States falling short of their obligations to refugees in terms of securing international protection seems to be rather compelling.

\section{Conclusion}

It must be acknowledged that both the EU and some Member States have contributed greatly to the protection of refugees and continue to do so. However, given the unprecedented rise in asylum seekers, in light of the comparison between the meager hosting numbers of the EU and those of host countries in the developing world, and considering the dereliction of adequate human rights protection elsewhere, we could say that many EU States and the EU itself failed to fulfil their moral obligations towards refugees in some 
respects. Not only according to ideal approaches in normative theory, but also according to the very values on which the EU stands. The Treaty on the European Union (art. 2) establishes a very precise ethos as foundation for the EU:

The Union is founded on the values of respect for human dignity, freedom, democracy, equality, the rule of law and respect for human rights, including the rights of persons belonging to minorities. These values are common to the Member States in a society in which pluralism, non-discrimination, tolerance, justice, solidarity and equality between women and men prevail

In fact, the EU is often defined and it has often defined itself as a normative or ethical actor (BuLley 2017, 53). Perhaps, one could argue that such an ethos is meant in a communitarian sense - along the lines of Walzer's (I983) Spheres of Justice - and that the EU was always intended to protect its own, rather than others, with more responsibility for its people and Member States in an internal form of solidarity. However, the TEU itself declares that one of the Union's central aims is to promote these values both at home and in "its relations with the wider world" by contributing to "peace, security", and other social goods, including "solidarity and mutual respect among peoples" (art. 3.5). This is why, although the EU is meant as an area of freedom, security and justice primarily for EU citizens, the Tampere European Council recognized that "it would be in contradiction with Europe's traditions to deny such freedom to those whose circumstances lead them justifiably to seek access to our territory" (Tampere European Council i 1999).

Consequently, we could very well say, that the EU understands itself as guarantor of a kind of cosmopolitan ethics, because it is founded on the respect to human dignity and to the human rights of all persons and not only of its own citizens. Therefore, failing to admit a certain number of refugees or to secure their human rights protection elsewhere, would be a blatant contradiction with the value of human dignity and with the EU foundational values. Thus, some of the EU's and its Member States' actions during the refugee crisis of 2015-2016 could be considered unjust and an expression of "organized hypocrisy" (Gibney 2004, 229).

However, it would be utterly unrealistic to expect EU States to comply with the demands of an ideal notion of justice. As Cortina puts it, "the task of practical reason is not only to state what should be, but also to take flesh in the institutions, transforming them from the inside" (2010).$^{11}$ In this sense, the question is, what moral suggestions could realistically be expected to "take flesh" in the institutions of the EU and its Member States?

${ }^{11}$ The translation is mine. 


\section{Suggestions: WHAT SHOUld THEY HAVE DONE?}

I present the following final remarks as merely brief sketches of some of the most relevant suggestions that can be drawn from the previous pages. They are by no means intended as an exhaustive list or a full explanation of proposals.

First, all EU countries should at least have honored their commitments in the frame of the EU relocation and resettlement plan by meeting their quotas and by doing so within the agreed deadlines. By failing to do that, their actions and omissions where utterly unethical.

Secondly, some EU countries should have admitted more refugees or should have made sure that a number of refugees enjoyed full human rights protection elsewhere -including long-term integration or a suitable substitute for it-. It is true that there is no international burden-sharing scheme to deal with refugee protection and it is also true that establishing fair share quotas for every country is an extremely complex issue (See MiLLER 20 19, 8693 or GibNEY 2004, 215-22). However, I believe the case can be made that, in the middle of the second greatest refugee crisis in history, granting asylum to zero refugees (Ireland, Poland, Croatia) would be considered unethical for any EU country, as probably would be hosting less than three hundred (Latvia, Slovenia, Slovakia, Estonia, Lithuania). That is, unless they effectively secured adequate protection elsewhere.

Admittedly, the magnitude of the refugee flow to Europe was alarming for EU governments and, in a non-ideal world, they were justified to fear severe consequences and long-lasting effects for their countries in terms of economic cost, political backlash, social unrest, etc. But even conceding that, the extremely restrictive and exclusive admission policies of some States should at least have been compensated by an effort to secure adequate protection in third countries.

Although in terms of ideal theory, I am inclined to agree that rich democratic countries should take up the slack and take in more refugees than their fair share would strictly demand (OwEN 2016), in the real-world scenario of the 2015 refugee crisis, I feel forced to agree with Miller (2019) that EU countries had no duty of justice to take up the slack, but merely to take in or otherwise effectively protect their fair share of refugees. Even Peter Singer, one of the most inclusive theorists, who in 2010 was still maintaining that affluent States should take in as many refugees as possible because the more fundamental needs of poor migrants were more important than the less fundamental ones of citizens (SINGER 20 IO), in 2015 proposed sending asylum claimants to refugee camps. He recognized that "it may not be the best solution, but it may be the most workable" (SINGER 2015). 
The previous concessions, however, do not mean that European countries were morally justified to not comply with their obligations to refugees, by refusing to admit a minimum number of refugees and by failing to provide acceptable protection elsewhere. Singer's (20 I 5 ) proposal was dependent upon two requirements: refugee camps in third countries must guarantee full human rights protection and such protection had to be paid by the affluent countries.

Massive refugee camps within the EU could have proven difficult to manage. If set up as open facilities, governments would have been looking at hundreds of thousands of asylum seekers potentially roaming the EU trying to settle down irregularly. On the other hand, if conceived of as detention camps, they would have been ethically most questionable from a liberal democratic perspective. Processing camps outside the EU, where asylum seekers are protected from persecution, their basic needs are covered, and they can undergo an effective and expedite eligibility process would perhaps have been best suited for an emergency situation like the 2015-2016 crisis.

Yet, in order for this suggestion to be ethically acceptable, processing camps could only be a short-term device. To avoid protracted encampment, resettlement should be a strict duty, like non-refoulement is (CARENS 2013). At the same time, fair share quotas of international protection should be established for every country, unless the international refugee system is to remain an "organized hypocrisy" (GIBNEY 2004). Such quotas should be calculated conservatively, so that they would only oblige States to take in a minimum of refugees, and with mandatory deadlines, so that the resettlement process flows and the encampment period does not lag, thus eroding refugee human rights protection.

A less inclusive consequence of this kind of policy is that it would oblige States to put in place, alongside effective determination processes, operational repatriation mechanisms for those who would be found not eligible. Again, this is not ideal. Ideally, I would side with unrestricted freedom of movement (CARENS 1992) and unconditional universal hospitality (CoRTINA 2015), but even the most inclusive ideal theorists, when it comes to make prescriptions aimed at having an actual effect on real governments, accept restriction of movement and limits to hospitality (CARENS 20I3; SINGER 20I 5 ).

Thirdly, the EU agreements with Turkey and with North African countries should have aimed more effectively at guaranteeing human rights protection for the millions of asylum seekers that were prevented from accessing EU territory by those same agreements.

Fourthly, EU States should have welcomed and even encouraged citizen involvement in resettling and integrating refugees. One of the main objections to increasing refugee protection efforts is that States have a greater duty with 
regard to the interests of their own citizens than towards those of aliens. Yet, States' obligations to their citizens should work both ways and not only in the sense of restricting entry and downsizing refugee protection. Many EU citizens were interested and even eager to help refugees. In fact, civil society organizations played a major role in saving lives in the Mediterranean. The Spanish NGO Proactiva Open Arms, for instance, rescued 59,247 people from September 2015 to May 2018 (Proactiva Open Arms n.d.).

In addition, other organizations worked actively and effectively to help resettling and integrating refugees in EU countries. For instance, the "Humanitarian Corridors" set up by the St. Egidio Community, together with the Waldensian and Methodist Churches, made possible the resettlement of thousands of refugees from Lebanon and Jordan to Italy, France, Belgium, and Andorra. The whole scheme was managed in compliance with EU immigration security measures and to no cost to any government. It also provided integration guarantees for refugees through their introduction into a wide social network, provision of health care, education, and access to the labor market (SANT' EGIDIO 2019). Unfortunately, most EU governments did not allow this kind of initiatives to take place in their countries. I believe that liberal democratic States should work in conjunction with active citizens with regard to providing refugee protection through search and rescue operations, first asylum, resettlement and integration schemes, or advocacy campaigns. States should not force their citizens to accept more refugees than justice demands, but neither should they impede that their citizens act effectively in favor of refugees.

Many other considerations could be made with regards to the EU response to the refugee crisis in 2015-2016. The obligations of other countries, the obligations of the UNHCR and other international organizations, the duties of refugees, and other issues could and should be taken into consideration. However, because of the complexity of the issue, I have decided to limit the scope of this paper to an ethical assessment of the EU's and its Member States' fulfilment of their moral obligations to host refugees during that crisis. On the one hand, such assessment has allowed us to conclude that some of their actions were ethically questionable or even unjust. On the other hand, it has permitted us to offer a limited number of suggestions on how they could have done better and could do better in the future. 


\section{BIBLIOGRAPHY}

Ardittis, S. 20i6, "Is the EU Gradually Renouncing its Fundamental Values in Order to Better Protect its External Borders?", Ethics and International Affairs. Retrieved from https:/www.ethicsandinternationalaffairs.org/2016/eu-gradually-renouncing-fundamental-values-order-better-protect-external-borders [accessed November 9, 2018].

Barbulescu, R. 20i6, "Still a Beacon of Human Rights? Considerations on the EU Response to the Refugee Crisis in the Mediterranean", Mediterranean Politics. http://dx.doi.org/10.1080/13629395.2016.1194546

Betts, A. 2015, "The Normative Terrain of the Global Refugee Regime", Ethics and International Affairs 29(4). Retrieved from https://www.ethicsandinternationalaffairs.org/2015/the-normative-terrain-of-the-global-refugee-regime/ [accessed May 3, 2018].

Betts, A.; Collier, P. 2017, Refuge: Transforming a broken refugee system, St. Ives: Penguin Book.

Bulley, D. 20 I7, "Shame on EU? Europe, RtoP, and the Politics of Refugee Protection", Ethics and International Affairs 31(1): 51-70. https://doi.org/10.1017/ S0892679416000666

Carens, J. I992, "Migration and morality: a liberal egalitarian perspective", B. BARry and R. Goodin (ed.), Free movement: ethical issues in the transnational migration of people and money, University of Pennsylvania Press, 25-47.

Carens, J. 2013, The ethics of immigration, Oxford: Oxford University Press.

Cherem, M. 20 16, "Refugee Rights: Against Expanding the Definition of a 'Refugee' and Unilateral Protection Elsewhere”, Journal of Political Philosophy 24(2): 183-205. doi: 10.1111/jopp.12071

Cortina, A. 2010, Justicia cordial, Madrid: Trotta.

Cortina, A. 2015 , "Hospitalidad cosmopolita", El País, December 5.

Cortina, A.; Torreblanca, I. 20i6, "Decálogo para la crisis de los refugiados", El País, March 10.

Cortina, A. 20I7, Aporofobia, el rechazo al pobre. Un desafio para la democracia, Barcelona: Paidós.

Council of the EU 20 I 5 A, “Justice and Home Affairs Council, 20/07/2015.” Retrieved from http://www.consilium.europa.eu/en/meetings/jha/2015/07/20/ [accessed May 28, 2018].

Council OF THE EU 2015B, "Resolution of the Representatives of the Governments of the Member States meeting within the Council on relocating from Greece and Italy 40000 persons in clear need of international protection." Retrieved from http://data.consilium.europa.eu/doc/document/ST-111312015-INIT/en/pdf [accessed June 2, 2018]. 
Council of the EU 20 I 5c, “Justice and Home Affairs Council, 22/09/2015.” Retrieved from http://www.consilium.europa.eu/en/meetings/jha/2015/09/22/ [accessed June 2, 2018].

Donors n.d., "UNHCR, The UN Refugee Agency.” Retrieved from http://www. unhcr.org/donors.html [accessed May 30, 2018].

European Commission 20i6, "Communication from the Commission to the European Parliament, the European Council, the Council and the European Investment Bank on establishing a new Partnership Framework with third countries under the European Agenda on Migration”, June 7. Retrieved from http://ec.europa.eu/dgs/home-affairs/what-we-do/policies/european-agendamigration/proposal-implementation-package/docs/20160607/communication_external_aspects_eam_towards_new_migration_ompact_en.pdf [accessed July 24, 2018].

European Commission 20 i7a, "Commission Recommendation of 27.9.2017 on enhancing legal pathways for persons in need of international protection." Retrieved from https:/ec.europa.eu/home-affairs/sites/homeaffairs/files/ what-we-do/policies/european-agenda-migration/20170927_recommendation_on_enhancing_legal_pathways_for_persons_in_need_of_international_protection_en.pdf [accessed January 11, 2018].

European Commission 20i7B, "Report from the Commission to the European Parliament, the European Council and the Council", Annex 6.

European Commission n.d., "Forced displacement: refugees, asylum-seekers and internally displaced people (IDPs)." Retrieved from http://ec.europa.eu/echo/ what-we-do/humanitarian-aid/refugees-and-internally-displaced-persons_en [accessed June 26, 2018].

European Parliament 20I7, EU migrant crisis: facts and figures, June 30. Retrieved from http://www.europarl.europa.eu/news/en/headlines/society/ 20170629STO78630/eu-migrant-crisis-facts-and-figures [accessed June 12, 2018].

Foster, M. 2007, "Protection elsewhere: the legal implications of requiring refugees to seek protection in another state", Michigan Journal of International Law 28: 223-86.

Gibney, M. 2004, The Ethics and Politics of Asylum. Liberal Democracy and the Response to Refugees, Cambridge: Cambridge University Press.

Gibney, M. 2015, "Refugees and Justice between States", European Journal of Political Theory, online early: 1-17.

Gibney, M. 2018, “The ethics of refugees”, Philosophy Compass 13(10): 1-9. https://doi.org/10.1111/phc3.12521

Glossary n.d., "UNHCR Global Focus.” Retrieved from http://reporting.unhcr. org/glossary/r [accessed February 12, 2019]. 
Gogou, K. 2017, “The EU-Turkey deal: Europe’s year of shame.” Retrieved from https://www.amnesty.org/en/latest/news/2017/03/the-eu-turkey-deal-europesyear-of-shame/ [accessed March 23, 2018].

Hsu, R. 2017, "Global Europe: Rethinking migration, democracy, and what sustains Europe at home at abroad." Retrieved from: http://recursos.ufv.es/docs/HSURoland-eng.pdf [accessed February 17, 2019].

IraQ n.d., "European Civil Protection and Humanitarian Aid Operations of the European Commission website." Retrieved from http://ec.europa.eu/echo/where/ middle-east/iraq_en [accessed May 5, 2018].

Joint Ngo Statement ahead of the European Council of 28-29 June 2016. NGOs strongly condemn new EU policies to contain migration, s.f., Oxfam website. Retrieved from https://www.oxfam.org/sites/www.oxfam.org/files/file_attachments/jointstatementeumigrationresponse.pdf [accessed June 6, 2018].

Jordan n.d., "European Civil Protection and Humanitarian Aid Operations", European Commission website. Retrieved from http://ec.europa.eu/echo/where/ middle-east/jordan_en [accessed May 5, 2018].

Lebanon n.d., "European Civil Protection and Humanitarian Aid Operations", European Commission website. Retrieved from http://ec.europa.eu/echo/where/ middle-east/lebanon_en [accessed May 5, 2018].

Majcher, I. 2017, "Border Securitization and Containment vs. Fundamental Rights: The European Union's 'Refugee Crisis”, Georgetown Journal of International Affairs. Retrieved from https://www.georgetownjournalofinternationalaffairs.org/ online-edition/border-securitization-and-containment-vs-fundamental-rightsthe-european-unions-refugee-crisis.

Miller, D. 2007, National Responsibility and Global Justice, Oxford: Oxford University Press.

Miller, D. 2016, Strangers in our midst, Cambridge, MA: Harvard University Press.

Miller, D. 2019, "Our responsibilities to refugees", M. Нoesch; L. Laube (ed.), 2018 ZIF Workshop "Studying Migration Policies at the Interface between Empirical Research and Normative Analysis", Bielefeld: ULB Münster, 37-49. doi:10.17879/95189441435

Muiznieks, N. 2015, "You're better than this, Europe", The New York Times, June 29. Retrieved from https://www.ny-times.com/2015/06/29/opinion/youre-better-than-this-eu-rope.html?_r=3 [accessed January 10, 2018].

Muiznieks, N. 20 I6A, "Diese Pläne sind schlict illegal", Tageschau. Retrieved from http://www.tagesschau.de/ausland/eu-tuerkei-fluechtlingskrise-101.html [accessed May 27, 2018].

Muiznieks, N. 20 i6в, "Safeguards needed for EU-Turkey migration deal", Euractiv. Retrieved from https://www.euractiv.com/section/justice-home-affairs/opinion/ safeguards-needed-for-eu-turkey-migration-deal/ [accessed July 28, 2018]. 
Muiznieks, N. 2016c, "Stop Your Backsliding, Europe", The New York Times. Retrieved from https://www.nytimes.com/2016/03/15/opinion/stop-yourbacksliding-europe.html [accessed October 9, 2018].

New York Declaration n.d., "Refugees and Migrants", UN website. Retrieved from https://refugeesmigrants.un.org/declaration [July 3, 2018].

Nussbaum, M. 20 I9, The Cosmopolitan Tradition: A Noble but Flawed Ideal, Harvard: Harvard University Press.

Owen, D. 20I6A, "In loco civitatis: on the normative basis of the institution of refugeehood and responsibilities for refugees", F. SAraH; L. Ypi (ed.), Migration in Political Theory, Oxford: Oxford University Press, 269-89.

Owen, D. 20г6в, "Refugees, fairness and taking up the slack: On justice and the international refugee regime." Moral Philosophy and Politics 3(2), 141-164.

Owen, D. 2019, "Refugees, EU ctizenship and the Common European Asylum System. A normative dilemma for EU integration", Ethical Theory and Moral Practice 22: 347-69. https://doi.org/10.1007/s10677-019-09973-x

Pakistan n.d., "European Civil Protection and Humanitarian Aid Operations" of the European Commission website.” Retrieved from http://ec.europa.eu/ echo/where/asia-and-pacific/pakistan_en [accessed May 7, 2018].

Proactiva Open Arms n.d., "Our Missions." Retrieved from https://www.proactivaopenarms.org/en/our-missions [accessed June 12, 2018].

SANDELIND, C. 20I7, "Costs of refugee admission and the ethics of extraterritorial protection", European Journal of Political Theory. https://doi. org/10.1177/1474885117738118

Singer, P. 2015 , "Escaping the refugee crisis". Retrieved from https://www.project-syndicate.org/commentary/escaping-europe-refugee-crisis-by-peter-singer-2015-09?barrier=accesspaylog [accessed April 19, 2020].

Singer, P.; Singer R. 20io, "The ethics of refugee policy", J. S. Fishrin, Population and Political Theory. Chichester: Wiley-Blackwell, 285-304.

SAnt' Egidio, 2019, Dossier sui corridoi umanitari in Italia, Francia, Belgio e Andorra. Retrieved from https://www.santegidio.org/downloads/Dossier-Corridoi-Umanitari-20190627-web.pdf.

Tampere European Council 1999, "Presidency Conclusions", 15 and 16 October, European Parliament website. Retrieved from http://www.europarl.europa.eu/summits/tam_en.htm [accessed January 19, 2019].

Turkey n.d., "European Civil Protection and Humanitarian Aid Operations", European Commission website. Retrieved from http://ec.europa.eu/echo/where/ europe/turkey_en [accessed May 6, 2018].

Uganda n.d., "European Civil Protection and Humanitarian Aid Operations", European Commission website. Retrieved from http://ec.europa.eu/echo/ where/africa/uganda_en [accessed May 6, 2018]. 
UNHCR 2015, UNHCR Statistical Yearbook 2014. Geneva: UNHCR. Retrieved from https://www.unhcr.org/56655f4d8.html [accessed April 7, 2018].

UNHCR 20I7A, Global Appeal. Geneva: UNHCR. Retrieved from http://www. unhcr.org/protection/resettlement/593a88f27/unhcr-projected-global-resettlement-needs-2018.html [accessed November 11, 2018].

UNHCR 2017в, Global Trends. Forced Displacement in 2016. Geneva: UNHCR. Retrieved from https://www.unhcr.org/5943e8a34.pdf [accessed May 8, 2018].

UNHCR 2017C, UNHCR Statistical Yearbook 2016. Geneva: UNHCR. Retrieved from http://www.unhcr.org/statistics/country/5a8ee0387/unhcr-statisticalyearbook-2016-16th-edition.html [accessed April 7, 2018].

United Nations 20i6, "Resolution 71/1. New York Declaration for Refugees and Migrants", New York. Retrieved from http://www.un.org/en/ga/search/ view_doc.asp?symbol=A/RES/71/1 [accessed March 24, 2018].

Walzer, M. I983, Spheres of Justice, New York: Basic Books.

Wellman, C. H.; Cole, P. 201 I , Debating the Ethics of Immigration. Is there a Right to Exclude?, Oxford: Oxford University Press.

Wellman, C. H. 2016, "Freedom of movement and the rights to enter and exit", Fine, S; Y YI, L. (ed.), Migration in Political Theory, Oxford: Oxford University Press, 80-101. 
